\title{
The Effect of Snakehead Fish (Channa striata) Extract on Inflammation Reaction of Skin Wound Tissue in Rattus novergicus Wistar Strain
}

\author{
Nanda Amalia Ramadhanti' ${ }^{1}$, Willy Sandhika², Agung Dwi Wahyu Widodo ${ }^{3}$ \\ ${ }^{I}$ Medical Education Program at The Faculty of Medicine Universitas Airlangga, Surabaya, Indonesia \\ ${ }^{2}$ Departement/Medical Staff of Anatomic Pathology Faculty of Medicine, Universitas Airlangga, Dr. \\ Soetomo General Academic Teaching Hospital, Surabaya, Indonesia \\ ${ }^{3}$ Departement/Medical Staff of Microbiology Faculty of Medicine, Universitas Airlangga, Dr. Soetomo \\ General Academic Teaching Hospital, Surabaya, Indonesia
}

\begin{abstract}
Background: Snakehead fish has been associated with wound healing due to its high albumin content. Albumin can accelerate the inflammatory process so that tissue repair will be faster. Lack of albumin protein causes a person tend to experience prolonged wound healing. Purpose: This study aims to prove the effect of snakehead fish extract on the number of macrophages and blood vessels on the inflammatory reaction of skin wound tissue in rats. Methods: Laboratory experimental design with a total sample size of 27 male rats have undergone incisions, divided into 3 random groups: control group was given aquadest, treatment group 1 was given aquadest and 50\% extract of snakehead fish, and treatment group 2 was given $100 \%$ extract of snakehead fish. The rat's skin wound tissues were taken on day 5 and observed under the microscope. The average number of macrophages and blood vessels on granulation tissue that formed at the base of the wound were counted and then performed data analysis. Result: In this study, we found a down wards trend in the average number of macrophages and blood vessels in treatment group 1 and treatment group 2. The control group and the treatment group 2 showed a significant difference, however, between the other groups did not show significant difference. Conclusion: There is a significant effect of giving $100 \%$ snakehead fish extract on decreased macrophages and blood vessels in the inflammatory reaction of skin wound tissue.
\end{abstract}

Keywords: wound healing, snakehead fish, macrophages, blood vessels.

Correspondence: Willy Sandhika, Departement/Medical Staff of Pathology Anatomy Faculty of Medicine Universitas Airlangga/Dr. Soetomo General Hospital. -Mayjend Prof. Dr. Moestopo Street No. 6-8 Surabaya 0131, Indonesia. Phone number: +628123293120, e-mail: willysand@fk.unair.ac.id.

\section{BACKGROUND}

Snakehead fish (Channa striata) has been used since a long time ago and now it has proven its medical benefits. This benefit is closely related to the content of snakehead fish that is high levels of albumin. Albumin plays an important role related to wound healing. Various factors are needed in wound healing including nutritional factors that can be obtained from protein albumin. It was stated that patients with normal nutritional status, measured by body mass index and albumin levels, had better post-operative wound healing rates compared to malnourished patient. ${ }^{1}$ The results of another study stated that $36.7 \%$ of patients who had abnormal albumin levels before surgery had a 5.1 times risk of not recovering from those who had normal albumin levels. ${ }^{2}$ Another study in Surakarta also found comparable results, $37.5 \%$ of patients at risk of not recovering due to having abnormal albumin levels before surgery. ${ }^{3}$ There was also research that mentions most puerperal mother that was lacking in protein consumption experienced a long healing condition of the perineal wound. ${ }^{4}$ Lastly, it was mentioned that in hypoalbuminemia patients, as many as $55.6 \%$ of them, experienced poor wound healing. ${ }^{1}$

With the results of these studies, albumin is associated with wound healing. Albumin, which is contained in snakehead fish extract, plays a role in accelerating inflammatory process so that the repair tissue process will be faster. ${ }^{5}$ Albumin also has various receptors that play a role in wound healing such as albondin (gp60), gp18, gp30, and SPARC (Secreted Protein Acidic and Rich in Cysteine) which are expressed on macrophages, fibroblasts, endothelium, and other cells. ${ }^{6}$ Albumin acts as an amino acid transport agent by binding to tryptophan and cysteine, which can regulate and maintain protein synthesis in the wound area and stimulate collagen formation. Another role is to stimulate transforming growth factor (TGF) by macrophages, which will increase cell migration, fibroblast proliferation, and granulation tissue formation. Albumin is also rich in essential and non-essential amino acids such as lysine, glycine, 
aspartic acid, and glutamic acid which are important components to accelerate the process of tissue repair and healing. ${ }^{7,8}$ In addition, albumin also binds Zinc ( $\mathrm{Zn})$ and fatty acids, which also contained in snakehead fish extract, to help regulate prostaglandin synthesis which activates the macrophages system. ${ }^{9}$ With a variety of benefits and amino acid content in albumin, snakehead fish (Channa striata) is widely used in the process of wound healing.

This study aims to look at the number of macrophages and blood vessels in the granulation tissue that formed at the base of the wound after giving snakehead fish extract. Granulation tissue is growth of new tissue that occurs when wound experience a healing process. It consists of macrophages, blood vessels and fibroblasts. ${ }^{10}$ When using snakehead fish extract, the granulation tissue area narrowed faster that indicating lower inflammation. ${ }^{11}$ With the substances of snakehead fish extract which can accelerate the inflammatory process, fewer macrophages and blood vessels are found in the granulation tissue. Macrophages play a role in the phase of inflammation and proliferation will appear about 24 hours after injury by phagocytosis of cells undergoing apoptosis. ${ }^{12}$ Whereas blood vessels will form in the proliferation phase which involves endothelial cell proliferation.

\section{METHODS}

This research is an experimental analytic study using Rattus novergicus Wistar strain with a simple randomization method. The approach used in this study is posttest-only control group design. Experimental animals will be put into 3 groups, consisting of 1 control group and 2 treatment groups. Control group was given aquadest, treatment group 1 was given 50\% extract of snakehead fish and aquadest, treatment group 2 was given $100 \%$ extract of snakehead fish. All groups will be treated for 5 days, then it will be observed through histopathological features. This research hypothesizes that there is a decrease in the number of macrophages and blood vessels in the administration of $50 \%$ and $100 \%$ snakehead fish (Channa striata) extract in accelerating wound healing in Rattus novergicus Wistar strains.

The sample used in this study was Rattus novergicus Wistar strain obtained from the Laboratory of Biochemistry, Faculty of Medicine, Universitas Airlangga. In this study, experimental animals were randomly selected but still met the criteria. Samples were taken by simple randomization method because the samples were considered homogeneous after fulfilling the inclusion and exclusion criteria. Inclusion criteria: sex of male rats, age of rats between 8-12 weeks, the weight of rats between 100-200 grams, and obtained from the same breed and given the same feed. Exclusion criteria: animals die during the adaptation period, look sick during the adaptation period including not actively moving, there is a bite wound on the body and liquid stools, also visible stress during the adaptation period which is characterized by weight loss of more than $10 \%$. By using the Federer formula (1997), from the 3 groups obtained the number of samples in each group is a minimum of 9 experimental animals.

The sample used was 27 Rattus novergicus Wistar strain. After going through the process of adaptation in the Laboratory of Biochemistry, Faculty of Medicine, Universitas Airlangga, experimental animals are fasted 3-4 hours before being treated. Then anesthetized by giving ketamine $45 \mathrm{mg} / \mathrm{kg}$ intramuscularly. Next, the hair on the back will be cut and continued with the administration of 1-1.5 cm long cut and 2-3 mm deep wound using a scalpel. For standard wound care saline, povidone-iodine, then covered with gauze (transparent dressing). The administration of snakehead fish extracts and aquadest to the sample begins 1 day after the wound was administered at a dose of $0.5 \mathrm{~mL} / 10 \mathrm{~g}$ per day. ${ }^{9}$ The extract in liquid form was pasteurized by heating $50^{\circ}$ Celcius for 15 minutes to kill microbes, then it was stored at maintained temperature of $4^{\circ}$ Celcius until it will be used. ${ }^{13}$ Every day, the surveillance of Rattus novergicus Wistar strain is carried out in order to meet the inclusion criteria. After 5 days, skin tissue is taken to make histopathological preparations. The staining will be done is Hematoxylin Eosin (HE) to see the number of macrophages and blood vessels. Microscopic data collection was carried out at the Anatomical Pathology Laboratory, Faculty of Medicine, Universitas Airlangga. Histopathological features were seen under a light microscope with magnification of 400x and made comparisons between each sample group. The way of counting and reporting the result was taught and supervised by an expert pathologist.

The purpose of the analysis in this study was to compare the control group and the treatment group. Measurement of the number of macrophages and blood vessels from the experimental animal sample produced data, then processed with quantitative descriptive analysis and continued with statistical tests using the Statistical Program Service Solution (SPSS) version 23. For groups of macrophages that were categorized, Kruskal Wallis test was performed. Then, further analysis was carried out using Post Hoc Mann-Whitney $\mathrm{U}$ test to determine the degree of difference in the influence of each group. The data of blood vessels would be tested for normality using Saphiro-Wilk and homogeneity test using Levene. If from the normality 
and homogeneity test the data is declared normal $(\mathrm{p}>$ 0.05 ) and homogeneous ( $p>0.05)$, then the blood vessel data will be continued with the One Way ANOVA statistical test at the $95 \%$ confidence degree ( $p<0.05$ ) with $\alpha=0.05$. Furthermore, the analysis was carried out using Tukey's Post Hoc to determine the degree of difference in the influence of each group.

This research has been through the Ethics Committee review in the Faculty of Medicine, Universitas Airlangga and did not get sponsors from the snakehead fish extract factory so this research was objective.

\section{RESULT}

The study obtained histopathology images of macrophages and blood vessels in granulation tissue with the staining Hematoxylin Eosin (HE). Macrophages feature is amoeboid shaped with round or oval nucleus and medium size (15 - 80 um). The cytoplasm is clear and has many vacuoles. While the capillary blood vessels are bright red that has cavities filled with erythrocytes, surrounded by endothelial cells without the presence of smooth muscle.

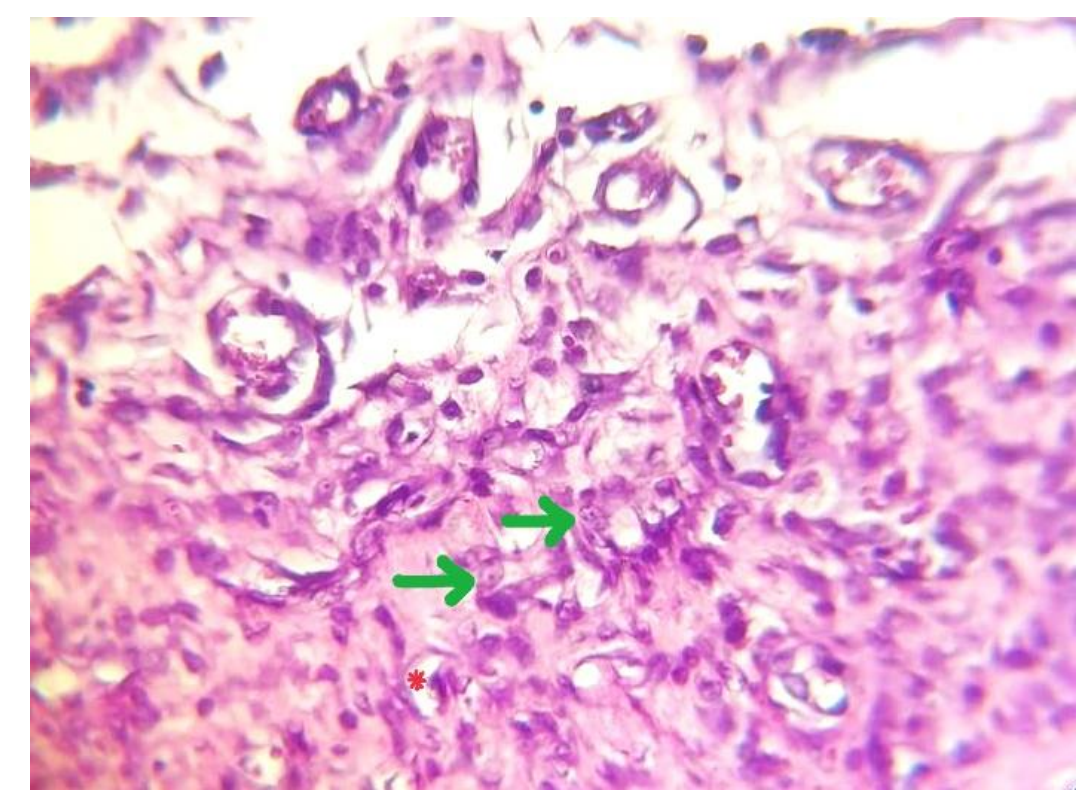

Figure 1. Microscopic images of laboratory rat skin lesions treated with snakehead fish extract on day 5 (magnification 400x, Hematoxylin Eosin).

Note: $(\rightarrow)$ Image of macrophage cells, $(*)$ Image of blood vessel.

The data on the number of macrophages were categorized for each treatment, namely category 1 for the number of macrophages $0-15$, category 2 for the number of macrophages 16-31, and category 3 for the number of macrophages 32-47. The results obtained from the calculation of all categories of each treatment have the same median value and mode, with the frequency of the largest data is in the number of macrophages 16 to 31 .

Table 1. Mean rank for the number of macrophages in the granulation tissue on day 5

\begin{tabular}{lll}
\hline Variable & Groups & Mean Rank \\
\hline Macrophages & Control & 4893 \\
& Treatment 1 & 39.78 \\
& Treatment 2 & 34.30
\end{tabular}

Table 1 shows the mean rank of control group is higher than treatment group 1, while the mean rank of treatment group 1 is higher than treatment group 2. So clinically based on the result, the higher concentration of snakehead fish (Channa striata) extract produce the lower number of macrophages in rats. Furthermore, the different effect of snakehead fish extract was tested on the number of macrophages using the Kruskal Wallis test. Obtained a p-value of 0.022 which is less than the critical limit of 0.05 . That means at least one pair of treatments is significantly different from the number of macrophages. 
Table 2. Statistical result of post hoc mann-whitney rest for the number of macrophages in the granulation tissue on day 5

\begin{tabular}{llll}
\hline Treatment & & Sig & Decision \\
\hline Control & Treatment 1 & 0.071 & No difference \\
Control & Treatment 2 & 0.012 & There is difference \\
Treatment 1 & Treatment 2 & 0.238 & No difference \\
\hline
\end{tabular}

Table 2 is the result of Mann-Whitney U test to determine the difference in the effect between each group with the criteria that if one treatment pair results in a probability $\leq$ level of significance $(\alpha=5 \%)$. The result of the analysis showed that the control group that was only given aquadest, produced the highest average number of macrophages and was significantly different from the treatment group 2 that given $100 \%$ extract of snakehead fish (Channa striata). Meanwhile, between the control and treatment group 1, also treatment group 1 and treatment group 2 did not produce a significant difference which means there was no difference.

Table 3. Mean and standard deviation for the number of blood vessels in the granulation tissue on day 5

\begin{tabular}{lllll}
\hline & & $\mathrm{N}$ & Mean & Standard Deviation \\
\hline Blood vessels & Control & 9 & 8.0367 & 1.63922 \\
& Treatment 1 & 9 & 7.1367 & 2.30433 \\
& Treatment 2 & 9 & 5.2967 & 1.51461 \\
& Total & 27 & 6.8233 & 2.12529 \\
\hline
\end{tabular}

For the number of blood vessels, table 3 informed the mean and standard deviation of blood vessels in rats from 3 groups. For the control group that was only given aquadest, the average number of blood vessels was $8.04 \pm 1.64$. Furthermore, treatment group 1 that given $50 \%$ extract of snakehead fish had an average number of blood vessels $7.14 \pm 2.30$. In the treatment group 2 that given $100 \%$ extract of snakeheadfish had average number of blood vessels $5.29 \pm 1.51$. Based on the descriptive analysis of the three groups, it can be seen that the treatment group with $100 \%$ extract of snakehead fish resulted in the lowest average number of blood vessels, while the control group that was only given aquadest had the highest average number of blood vessels.
On blood vessel data, the normality test was performed using the Shapiro Wilk test and the homogeneity test was carried out using Levene Test, using criteria if the probability value was above the level of significance $(\alpha=5 \%, p>0.05)$. It was found that the results of blood vessel data met the assumptions of normality and homogeneity. Furthermore, a difference test in the effect of giving snakehead fish extract on the number of blood vessels was carried out using One Way ANOVA which resulted in an $\mathrm{F}$ test statistic of 5.117 with a probability of $0.014(p<0.05)$. This means that in the number of blood vessels, it is stated that there is at least one pair of treatments that differ significantly in the administration of snakehead fish extract.

Table 4. Statistical result of post hoc tukey test for the number of blood vessels in the granulation tissue on day 5.

\begin{tabular}{llll}
\hline Treatment & & Sig & Decision \\
\hline Control & Treatment 1 & 0.565 & No difference \\
Control & Treatment 2 & 0.012 & There is difference \\
Treatment 1 & Treatment 2 & 0.109 & No difference \\
\hline
\end{tabular}

Then, further analysis was carried out using Tukey's Post Hoc test in table 4 to determine the difference in the effect between each group with the probability criteria $\leq$ level of significance $(\alpha=5 \%)$. The results of the analysis showed that the control group that was only given aquadest, produced the highest average number of macrophages and was significantly different from the treatment group 2 that given $100 \%$ extract of snakehead fish (Channa striata).
Meanwhile, between the control and the first treatment group, also the treatment group 1 and treatment group 2 did not produce a significant difference which means there was no difference.

\section{DISCUSSION}

Based on table 1 and table 3, it is known that the lowest average number of macrophages and blood vessels was produced in treatment group 2 by giving 
$100 \%$ extract of snakehead fish, followed by the treatment group 1 that was given aquadest and 50\% extract of snakehead fish. Then the highest was the control group that was only given aquadest. Afterward proceed with Mann-whitney U for macrophages and blood vessels, which showed that the control group in rats that were only given aquadest produced the highest average number of macrophages and blood vessels and was significantly different from the second treatment group that was given $100 \%$ extract of snakehead fish, which means there is a significant effect. These results are comparable to research by Hartini et al, 2015 which states that there is a significant decrease in the number of macrophages in rats that given snakehead fish (Channa striata) extract. $^{14}$

In the healing process, the wound goes through three phases, namely inflammation, proliferation, and remodeling. The two stages in the inflammatory phase are hemostasis and phagocytosis. Afterwards there will be proliferation. In this phase, there will be many processes, starting from granulation tissue formation, stimulating fibroblasts to form collagen-based scar tissue, the process of angiogenesis, and reepithelialization. The last is the remodeling phase which aims to achieve maximum tensile strength through reorganization, degradation, and re-synthesis of the extracellular matrix. ${ }^{15}$ The wound healing process begins with granulation tissue. It is growth of new tissue that occurs when wound experience a healing process. ${ }^{10}$ The granulation tissue replaces the initial matrix of fibrin and acts as an intermediary cell in the migration. This tissue appears the fourth day after the wound and consists of fibroblast cells, macrophages, and endothelium. ${ }^{16}$

Macrophages are one of the cells found in the granulation tissue that formed at the base of the wound. Macrophages are divided into two types of activation. M1 is an active or pro-inflammatory macrophage that expresses various proinflammatory mediators and cytokines that play a role in the phagocytosis of bacteria, foreign bodies, damaged tissue components, and apoptotic neutrophils. When the inflammatory process is complete, macrophages turn activated or become M2 (anti-inflammatory macrophages) which support cell proliferation by expressing various antiinflammatory mediators, protease enzymes, and protease inhibitors, as well as growth factors such as vascular endothelial growth factor (VEGF) and TGF$\beta .^{17}$ This change from M1 to M2 causes the appearance number of macrophages to decrease when the inflammatory process has been completed. There will be fewer macrophages migrating into the tissue during the inflammatory phase when using snakehead fish (Channa striata) extract because of various substances contained in it can inhibit vasodilation of blood vessels. ${ }^{14}$ This is consistent with the results of research to prove that snakehead fish (Channa striata) extract has anti-inflammatory effects.

The main content of snakehead fish (Channa striata), namely albumin has receptors that are expressed on macrophages such as gp18 and gp30. ${ }^{6}$ Albumin is important to stimulate TGF- $\beta 1$ by macrophages, which will increase cell migration, fibroblast proliferation, and formation of granulation tissue. Albumin also binds to Zinc, which is contained in snakehead fish extract, to plays a role in reducing inflammation and stimulating re-epithelialization so that the ability of phagocytosis in the immune system and the process of destruction of microbes increase. Albumin also binds to unsaturated fatty acids, which is also contained in snakehead fish extract, to play an important role in helping regulate prostaglandin synthesis, a product that activates the macrophage system strongly and appears during the inflammatory phase. ${ }^{9,18}$ With the substances of snakehead fish extract which can accelerate the inflammatory process, fewer macrophages are found in the granulation tissue.

While the decrease number of blood vessels can be interpreted as lower inflammation. Decreased blood vessels indicate the narrowing of granulation tissue which is an early sign of the healing process, so that the wound can be said to cure. This means that the administration of snakehead fish (Channa striata) extract for 5 days can provide an effect in accelerating wound healing. Fibroblasts play an important role in producing Extracellular Matrix (ECM), while macrophages will stimulate the endothelium to form new blood vessels as an energy source in granulation tissue. ${ }^{16}$ High neovascularization in the control group indicates that the wound healing process has not been completed, in contrast to the group given $100 \%$ extract of snakehead fish (Channa striata). The high number of neocapillaries in the control group indicated wound healing in the proliferation phase that was still or had just begun. It is influenced by the number of macrophages that secrete Angiogenesis Factor (AGF) which stimulates the formation of endothelial ends at the end of blood vessels. The two of them work together to speed up the wound healing process. ${ }^{19}$ The decrease in the number of blood vessels in the treatment group may also be due to the decrease in the VEGF, TGF- $\beta$, and Basic Fibroblast Growth Factor (bFGF) ${ }^{20}$ So in the group given $100 \%$ snakehead fish extract, it can be said that the wound is getting a better cure.

The effect on blood vessels is related to the main content of snakehead fish (Channa striata) namely albumin. In the regeneration process, cells need protein 
including albumin for optimal tissue repair so it can accelerate inflammation in the wound. Albumin can increase cell permeability and antithrombotic cell transport substance. ${ }^{21}$ Albumin also binds $\mathrm{Zn}$ and Cuprum $(\mathrm{Cu})$ which can play role in reducing inflammation by binding and optimizing the function of the enzyme superoxide dismutation. ${ }^{14}$

In clinical practice, $100 \%$ extract of snakehead fish can be used to reduce inflammation in wounds and thus help accelerate wound healing, as also supported by previous studies that mentioned above. However, this study still has limitations. So that further researchers are advised to carry out immunohistochemical examinations to obtain more accurate calculation results, conduct research on inflammatory mediators, and try topical administration of snakehead fish (Channa striata) extract to compare the effectiveness with oral administration.

Based on the results of the research that has been described and also in accordance with the purpose of the study, it can be concluded that there is a significant effect of giving $100 \%$ extract of snakehead fish on the decreased number of macrophages and blood vessels in accelerating wound healing of rats. So it can be concluded that $100 \%$ snakehead fish (Channa striata) effective in accelerating wound healing in the inflammatory and proliferative phases.

\section{REFERENCES}

1. Said S, Taslim NA, Bahar B. Hubungan IMT dan kadar albumin berhubungan dengan penyembuhan luka. J Keperawatan Padjadjaran 2016;4(1):60-9.

2. Pararesthi NLGA, Putra KAH, Kurniyanta P. Hubungan antara kadar albumin dengan penyembuhan luka pada pasien pasca bedah di Rumah Sakit Umum Pusat Sanglah Denpasar. Intisari Sains Medis 2019;10(3):759-65.

3. Marjiyanto, Murtutik L, Suwarni A. Hubungan kadar albumin dengan penyembuhan luka pada pasien post operasi laparatomy di ruang mawar Rumah Sakit Slamet Riyadi Surakarta. J Ilmu Keperawatan Indonesia 2013;1(1):80-97.

4. Aziz SSD, Soemardini, Nugroho FA. Hubungan tingkat konsumsi protein, zat besi (Fe) dan zinc (Zn) dengan kondisi penyembuhan luka perineum derajat II pada ibu nifas. Majalah Kesehatan UB 2016;3(3):137-43.

5. Fauziah Sugiartanti M, Oesman D, Elfiah Fakultas Kedokteran U, Jember J1 Kalimantan U. Pengaruh kadar albumin serum terhadap penyembuhan luka pada pasien pascaoperasi laparotomi dan lumbotomi di RSD dr. Soebandi Jember. e-Jurnal Pustaka Kesehatan 2018;6(3):383-6.

6. Merlot AM, Kalinowski DS, Richardson DR.
Unraveling the mysteries of serum albumin-more than just a serum protein. Front Physiol 2014;5 AUG(August):1-7.

7. Chasanah E, Nurilmala M, Purnamasari AR, Fithriani D. komposisi kimia, kadar albumin dan bioaktivitas ekstrak protein ikan gabus (Channa striata) alam dan hasil budidaya. J Pascapanen dan Bioteknologi Kelautan dan Perikanan 2015;10(2):123-32.

8. Dahlan-Daud CK, Mat Jais AM, Ahmad Z, Md Akim A, Adam A. Amino and fatty acid compositions in haruan traditional extract (HTE). Bol Latinoam y del Caribe Plantas Med y Aromat 2010;9(5):414-29.

9. Sura GM, Carabelly AN, Apriasari L. Aplikasi ekstrak haruan (Channa striata) 100\% pada luka punggung mencit (Mus musculus) terhadap jumlah neutrofil dan makrofag. Pdgi 2013;62(2):41-4.

10. Liana Y, Utama YA. Efektifitas pemberian ekstrak daun betadine (Jatropha muitifida linn) terhadap ketebalan jaringan granulasi dan jarak tepi luka pada penyembuhan luka sayat tikus putih (Rattus norvegicus). J Kedokteran dan Kesehatan Publik Ilmu Fakultas Kedokteran Univ Sriwijaya 2018;5(3):114-23.

11. Tungadi R, Attamimi F, Sabu EF, Nugraha E. Percepatan penyembuhan luka oleh krim ikan gabus (Ophiocephalus striatus) terhadap luka kulit kelinci secara histopatologi. J Ilmu Kefarmasian Indonesia 2011;9(2):91-7.

12. Fatimatuzzahro N, Haniastuti T, Handajani J. Respon inflamasi pulpa gigi tikus Sprague Dawley setelah aplikasi bahan etsa ethylene diamine tetraacetic acid 19\% dan asam fosfat 37\%. Dent J (Majalah Kedokteran Gigi) 2013;46(4):190.

13. Asfar M, Tawali AB, Pirman, Mahendradatta. Extraction of albumin of a snakehead fish (Channa striata) at its isoelectric point. J Agercolere 2019;1(1):6-12.

14. Hartini PS, Dewi N, Hayatie L. Esktrak ikan haruan (Channa striata) menurunkan jumlah makrofag pada fase inflamasi proses penyembuhan luka. J Dentomaxillofacial Sci 2015;14(1):6-10.

15. Gonzalez ACDO, Andrade ZDA, Costa TF, Medrado ARAP. Wound healing - a literature review. An Bras Dermatol 2016;91(5):614-20.

16. Suryadi IA, Asmarajaya A, Maliawan S. Wound healing process and wound care. E-Jurnal Med Udayana 2013;2(2):254-72.

17. Koh TJ, DiPietro LA. Inflammation and wound healing: the role of the macrophage. Expert Rev Mol Med 2011;13 (July 2011):1-12.

18. Fitria M, Saputra D, Revilla G. Pengaruh papain getah pepaya terhadap pembentukan jaringan 
granulasi pada penyembuhan luka bakar tikus percobaan. J Kesehat Andalas 2014;3(1):73-6.

19. Isrofah, Sagiran, Afandi M. Efektifitas salep ekstrak daun binahong (Anredera Cordifolia (Ten) Steenis) terhadap proses penyembuhan luka bakar derajat 2 termal pada tikus putih (Rattus Novergicus). Muhammadiyah J Nurs 2015;2(1) :27-39.
20. Soepriadi I. Regenerasi dan penyembuhan. Jakarta: Sagung Seto; 2013. 7-11 p.

21. Tamales DAM, Dewi N, Rosida L. Extract of haruan (Channa striata) extract increasing reepithelialisation count in wound healing process on wistar rat's buccal mucosa. J Dentomaxillofacial Sci 2016;1(1):12-5. 